\title{
Water vapor transport in cases of South Atlantic Convergence Zone (SACZ)
}

\author{
Transporte de vapor de água em casos de Zona de Convergência do Atlântico Sull (ZCAS) \\ Transporte de vapor de agua en casos de Zona de Convergencia del Atlántico Sur (ZCAS)
}

Received: 09/28/2021 | Reviewed: 10/09/2021 | Accept: 10/16/2021| Published: 10/18/2021

\author{
José Felipe Gazel Menezes \\ ORCID: https://orcid.org/0000-0002-6430-2935 \\ Universidade Federal do Pará, Brazil \\ E-mail: jfgmenezes@gmail.com \\ Enilson Palmeira Cavalcanti \\ ORCID: https://orcid.org/0000-0001-5788-9486 \\ Universidade Federal de Campina Grande, Brazil \\ E-mail: enilson.cavalcanti@ufcg.edu.br \\ Eduardo da Silva Margalho \\ ORCID: https://orcid.org/0000-0002-0165-4319 \\ Universidade Federal do Ceará, Brazil \\ E-mail: eduardomargalho@gmail.com \\ Letícia Karyne da Silva Cardoso \\ ORCID: https://orcid.org/0000-0003-4670-7426 \\ Universidade Federal de Campina Grande, Brazil \\ E-mail: lekaryne@gmail.com \\ Matheus Richard Araújo \\ ORCID: https://orcid.org/0000-0002-7609-9110 \\ Faculdade FACI, Brazil \\ E-mail: Matheus.richard@uepa.br
}

\begin{abstract}
This case study analyzes water vapor flux that is vertically integrated into the atmosphere in episodes of the South Atlantic Convergence Zone (SACZ). The scope of this study is two cases that occurred between January and February 2018. We use the ERA-Interim reanalysis data from the European Center for Medium-Range Weather Forecasts (ECMWF) to build the maps of vertically integrated water vapor flux and its divergence. We use two $5^{\circ}$ by $5^{\circ}$ sub-areas, centralized over Belo Horizonte and São Paulo, as control for water vapor balance. The results point to the existence of water vapor transport from the Amazon region to Southeastern Brazil in association to the SACZ. Convergence areas of vertically integrated water vapor flux predominate along the Northwest-Southeast line. The two cases over the Belo Horizonte area presented an average of water vapor balance of -1.8 and $-12.9 \mathrm{~mm} /$ day. The average at the São Paulo area was -3.6 and $2.0 \mathrm{~mm} /$ day. The negative values indicate that precipitation exceeded evapotranspiration, that is, the area served as a water vapor sink.
\end{abstract}

Keywords: Water vapor balance; SACZ; Reanalysis.

\section{Resumo}

Neste estudo de caso foi analisado o transporte de vapor d'agua integrado verticalmente na atmosfera, em episódios de atuação da Zona de Convergência do Atlântico Sul (ZCAS). Foram selecionados dois casos entre janeiro e fevereiro de 2018. Foram utilizados dados de reanálises do ERA-Interim do European Centre for Medium-Range Weather Forecasts (ECMWF), para a construção dos mapas do fluxo de vapor d'água integrado verticalmente e da respectiva divergência. Duas subáreas de $5^{\circ}$ por $5^{\circ}$, centralizadas nas cidades de Belo Horizonte e São Paulo, as quais foram utilizadas como volume de controle para a realização de balanço de vapor d'água. Os resultados apontam para existência de transporte de vapor d'água da região amazônica para o sudeste do Brasil associado a atuação das ZCAS. Áreas de convergência do fluxo de vapor d'água integrado verticalmente predominam ao longo da linha noroeste - sudeste. O balanço de vapor d'água apresenta em média -1.8 e $-12.9 \mathrm{~mm} /$ dia para os dois casos apresentados sobre área Belo Horizonte, e de -3,6 e $2,0 \mathrm{~mm} /$ dia sobre área São Paulo, os valores negativos indicam que a precipitação excedeu a evapotranspiração, ou seja, atuando como sumidouro de vapor d'água.

Palavras-chave: Balanço de vapor d’água; ZCAS; Reanálise.

\section{Resumen}

En este caso de estudio, se analizó el transporte de vapor de agua integrado verticalmente a la atmósfera en episodios de acción en la Zona de Convergencia del Atlántico Sur (SACZ). Se seleccionaron dos casos entre enero y febrero de 2018. Se utilizaron datos del reanálisis ERA-Interim del Centro Europeo de Pronósticos Meteorológicos a Mediano Plazo (ECMWF) para construir los mapas de flujo de vapor de agua integrados verticalmente y la divergencia respectiva. 
Dos subáreas del 5 al 5, centralizadas en las ciudades de Belo Horizonte y São Paulo, que se utilizaron como volumen de control para realizar un balance de vapor de agua. Los resultados apuntan a la existencia de transporte de vapor de agua desde la región amazónica al sureste de Brasil asociado con el desempeño de ZCAS. Las áreas de convergencia de flujo de vapor de agua integrado verticalmente predominan a lo largo de la línea noroeste-sureste. El balance de vapor de agua tiene un promedio de -1.8 y $-12.9 \mathrm{~mm} /$ día para los dos casos presentados en el área de Belo Horizonte, y -3.6 y $2.0 \mathrm{~mm} /$ día en el área de São Paulo, los valores negativos indican que la precipitación excedió evapotranspiración, es decir, actúa como sumidero de vapor de agua.

Palabras clave: Balance de vapor de agua; ZCAS; Reanálisis.

\section{Introduction}

Tropical forests provide a large amount of humidity to the atmosphere and present high temperatures throughout the year, favoring convective regions. In addition, the vegetation transfers a large amount of water vapor to the atmosphere. Along with the privilege of having a great number of water resources, this region transfers an immense amount of humidity to the atmosphere. As the flux from the Tropical Atlantic Ocean passes through the Amazon region, it meets a geographic barrier (The Andes) that channels it to higher latitudes.

The attempt of predicting future climate arises concomitantly with the needs of the population considering the perspective for a better urban and logistical development of cities. We use numerical modeling as an alternative in meteorological research due to the scarce availability of data and observations regarding the upper air. When available, the data often present a considerable gap in both space and time info. This fact furthers the development and improvement of existing models, which consequently also improves the reanalysis data. The European Centre for Medium-Range Weather Forecasts (ECMWF) provides ERA-Interim, which has a higher resolution. Several forecasting centers in the country use its data as input in regional atmospheric modeling. They also generate numerous forecasts of meteorological variables using its output. It is instrumental for making fundamental decisions for better risk management in order to meet the needs of the population.

Licco \& Seo (2013) explains that there are currently more homeless people in the world as a result of natural disasters rather than conflicts. Studies carried out by Licco \& Mac Dowell (2015) indicate that this increase in the number of homeless people may be directly associated with global climate change. In this context, it is paramount to study the South Atlantic Convergence Zone (SACZ) to prevent losses and minimize the eventual damage for excess rainfall over the South and Southeast regions. The four states in the Southeast region (São Paulo, Minas Gerais, Rio de Janeiro, and Espírito Santo) together register $75.27 \%$ of the national total of deaths and endured 35.64\% of all cases of natural disasters (Licco \& Mac Dowell, 2015). This disproportion is due to the region's demographic density. If a natural disaster event affects two demographically distinct locations, it will be more severe where there is a higher number of inhabitants (CEPED/UFSC, 2013).

This paper studies the transport of water vapor, therefore we have selected areas around Belo Horizonte and São Paulo, in the Southeast region of the country, where the results are further perceivable. This article studies the humidity coming from the Amazon in the austral summer season, and the flux of water vapor from the South of the Amazon Basin that potentially leads towards the South and Southeast of Brazil due to the mountain range located on the western coast of South America (the Andes). This humidity transport is extremely important for the quality of the wet season in these regions. Such as for the occurrence and maintenance of the South Atlantic Convergence Zones (SACZ), one of the large-scale rain systems from December to February. In addition, Quadro et al. (2012) state that the Atlantic Ocean is the main source of humidity flux for the SACZ because local evaporation is insufficient to provide all the humidity for the total precipitation generated in the SACZ region.

The SACZ is a band of cloudiness and rainfall, with a Northwest-Southeast orientation, which extends from the Amazon to the South Atlantic Ocean (Kodama, 1992). Other large-scale phenomena also affect The SACZ. It is a system characteristically related to the summer period in the Southern hemisphere, presenting a significant release of latent heat that requires monitoring since the weather and climate in tropical regions are under the influence of such systems. 
We then analyzed the transport of water vapor in cases of the SACZ, focusing mainly on the Southeast of Brazil as the impact on this region is more expressive and devastating, causing greater socio-environmental and economic effects.

\section{Area, material and methods}

\subsection{Area location}

The research studies an area in South America, longitude: $80^{\circ} \mathrm{W}$ and $30^{\circ} \mathrm{W}$, latitude: $30^{\circ} \mathrm{S}$ and $2^{\circ} \mathrm{N}$ (Figure 1 ). There are also two subareas in blue (the control volumes) of $5^{\circ}$ by $5^{\circ}$ centralized in the cities of Belo Horizonte (the BH area) and São Paulo (the SP area), where the water vapor balances were made so that the flux out of the face is positive and influx is negative.

Figure 1: Location map of the study area, and two $5^{\circ}$ by $5^{\circ}$ sub-areas centered in Belo Horizonte (BH) and São Paulo (SP), Southeast Brazil, with the denomination in rectangle faces.

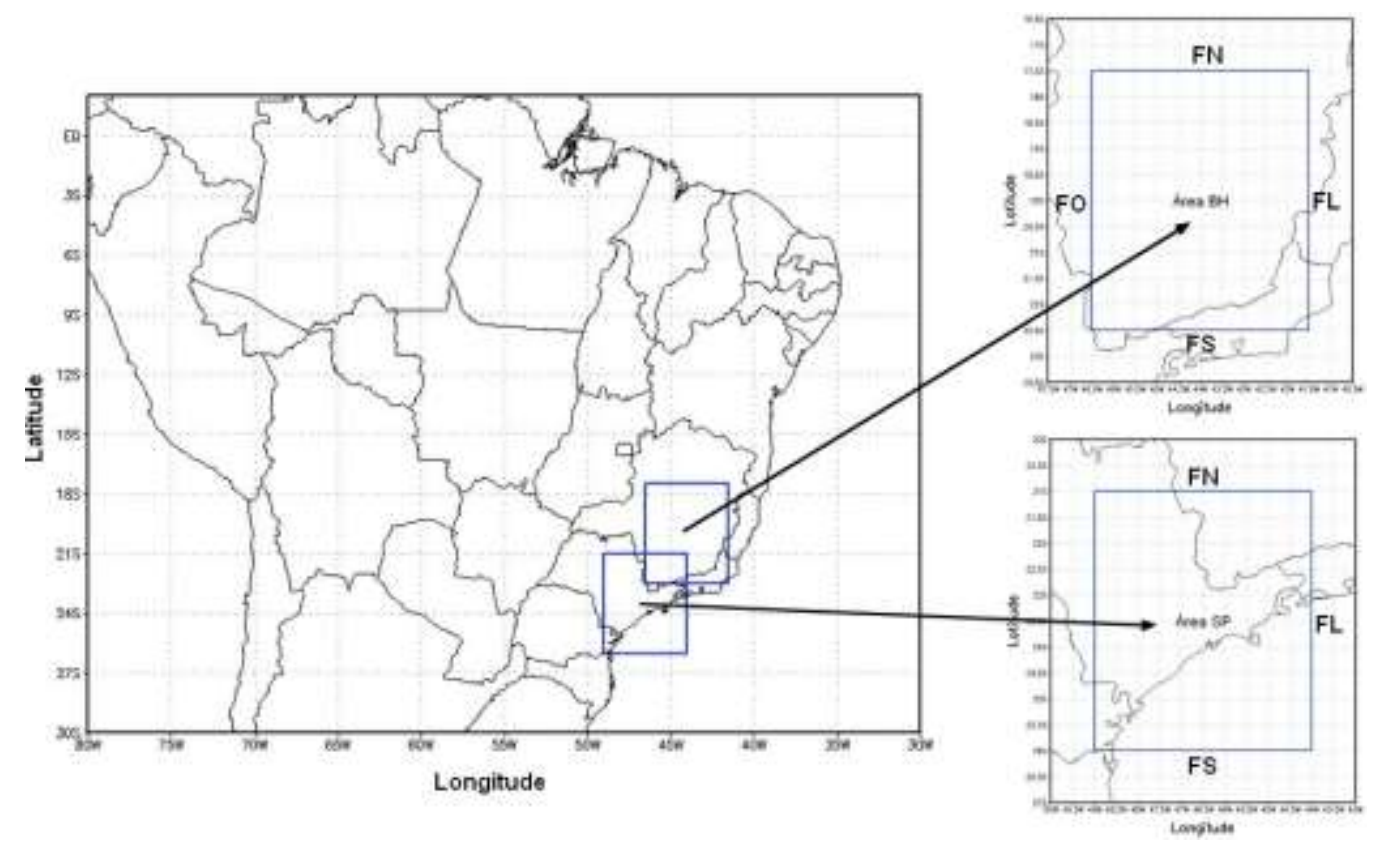

Source: Authors (2018).

\subsection{Materials}

The data used in this research come from the ERA-Interim, whose reanalysis information is provided by the European Center for Medium-Range Weather Forecasts (ECMWF). It was published in 2009 and is considered to be the successor of ERA40, which is the first-generation data. Dee et al. (2011) demonstrate how the ERA-Interim was originally designed to address several difficult data assimilation problems encountered during the ERA-40 production. The data period made available by ERAInterim is from January 1, 1979, to the present day. The horizontal resolution of the atmospheric model is approximately $79 \mathrm{~km}$ on a Gaussian grid. It was $125 \mathrm{~km}$ on the ERA-40. The model's vertical resolution currently comprises 60 levels, whose highest level is 0.1hPa. It is updated twice a day: 00:00 UTC and 12:00 UTC, although the four synoptic times are made available: 00:00 UTC, 06:00 UTC, 12:00 UTC, and 18:00 UTC (Stüker et al., 2016).

We obtained the surface synoptic charts for the target period (01/01/2018 - 03/14/2018) at the Center for Weather Forecast and Climatic Studies (CPTEC/INPE) to define occurrence cases of the SACZ, as well as the satellite images for the target periods. This case study will cover two events that took place between January and February 2018. 


\subsection{Methods}

\subsubsection{Calculations of vertically integrated water vapor flux}

The vertically integrated water vapor flux is vectorially represented as:

$$
\vec{Q}=Q_{\lambda} \vec{\imath}+Q_{\phi} \vec{\jmath}
$$

where $Q \lambda$ and $Q \phi$ are the components of zonal and meridional flow, respectively. According to Rao \& Marques (1984), they can be obtained by the vertical integral of the humidity flux multiplied by the $u$ and $v$ components of wind:

$$
\begin{aligned}
& Q_{\lambda}=\frac{1}{g} \int_{300}^{P s} q u d p \\
& Q_{\phi}=\frac{1}{g} \int_{300}^{P s} q v d p
\end{aligned}
$$

where: $g$ is the gravitational acceleration, and $d p$ is an infinitesimal element of vertical pressure. Integration is made from the surface $(P s)$ up to the $300 h P a$ level where the air humidity is virtually zero.

This information was obtained directly from the ECMWF database, through ERA-Interim Reanalysis. The parameters were previously calculated and described by Simmons and Burridge (1981).

Based on the information from zonal and meridional vertically integrated water vapor flux, we were able to evaluate the spatial distribution of divergence. The calculation used by finite differences, as follows:

$$
\nabla \cdot \vec{Q}=\frac{\partial Q_{\lambda}}{\partial x}+\frac{\partial Q_{\phi}}{\partial x}
$$

\subsubsection{Water vapor balance in Southeastern Brazil.}

According to Peixoto (1973) and Peixoto and Oort (1992), the resultant flux (FR) that enters or leaves through the faces of the Southeastern area was obtained from the expression:

$$
F R=\oint \vec{Q} \cdot \vec{n} d l
$$

where $\vec{n}$ is a unit normal vector, perpendicular to the face of the rectangle in the outward direction, and $d l$ is an infinitesimal element of this face.

Following the counterclockwise direction, the integration around the rectangle was carried out in parts called North face (FN), South face (FS), West face (FO), and East face (FL). Therefore:

$$
\begin{gathered}
F S=-k \int_{\lambda=-49^{\circ}}^{\lambda=-44^{\circ}} Q_{\emptyset=-26^{\circ} d \lambda} \\
F L=k \int_{\emptyset=-26^{\circ}}^{\emptyset=-21^{\circ}} Q_{\lambda=-44^{\circ} d \emptyset} \\
F N=k \int_{\lambda=-49^{\circ}}^{\lambda=-44^{\circ}} Q_{\emptyset=-21^{\circ} d \lambda}
\end{gathered}
$$




$$
F O=-k \int_{\emptyset=-26^{\circ}}^{\emptyset=-21^{\circ}} Q_{\lambda=-44^{\circ}} d \emptyset
$$

where $k$ is a conversion constant from degrees to meters, and $k=111 \times 10^{3} \mathrm{~m}$.

The positive values indicate flux leaving the area and negative values indicate flux entering the area. This way, the resulting flux (FR) is obtained from the sum of the faces, that is:

$$
F R=F S+F L+F N+F O
$$

Therefore, the positive resulting flux FR is associated with the source or export of water vapor. Negative values relate to the sink or import of water vapor in sub-areas BH or SP, Southeastern Brazil. These values can be expressed in $\mathrm{mm} /$ day, drawing the average over-area distribution in terms of rainfall.

\section{Results and Discussion}

\subsection{Case 1}

Case 1 (Figures 2 and 3) represents the first SACZ of 2018. In the early days of this episode, the SACZ was located over Minas Gerais. However, later it moved to the north of São Paulo, where it was possible to identify its influence in the subarea over São Paulo and Belo Horizonte. The case had an average span, and the cloudiness band remained for six days, from $01 / 04 / 2018$ to $01 / 09 / 2018$. 
Research, Society and Development, v. 10, n. 13, e455101321187, 2021

(CC BY 4.0) | ISSN 2525-3409 | DOI: http://dx.doi.org/10.33448/rsd-v10i13.21187

Figure 2: Satellite image in the enhanced infrared channel for the case 1 period at 18 UTC. A) B) C) D).
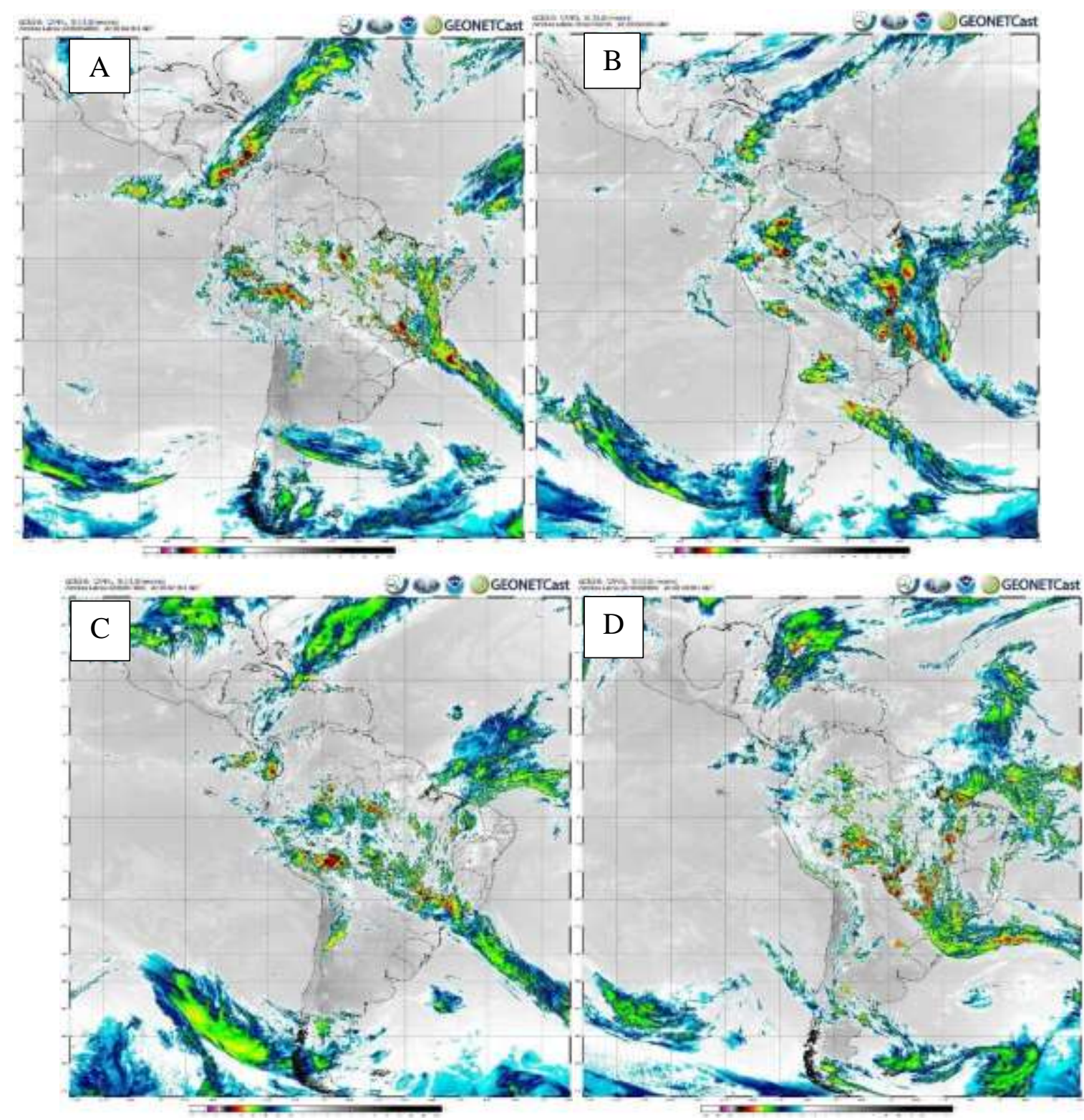

Source: DSA/CPTEC (2018). 
Figure 3: Surface synoptic charts for the case 1 period at 18 UTC. A) B) C) D).
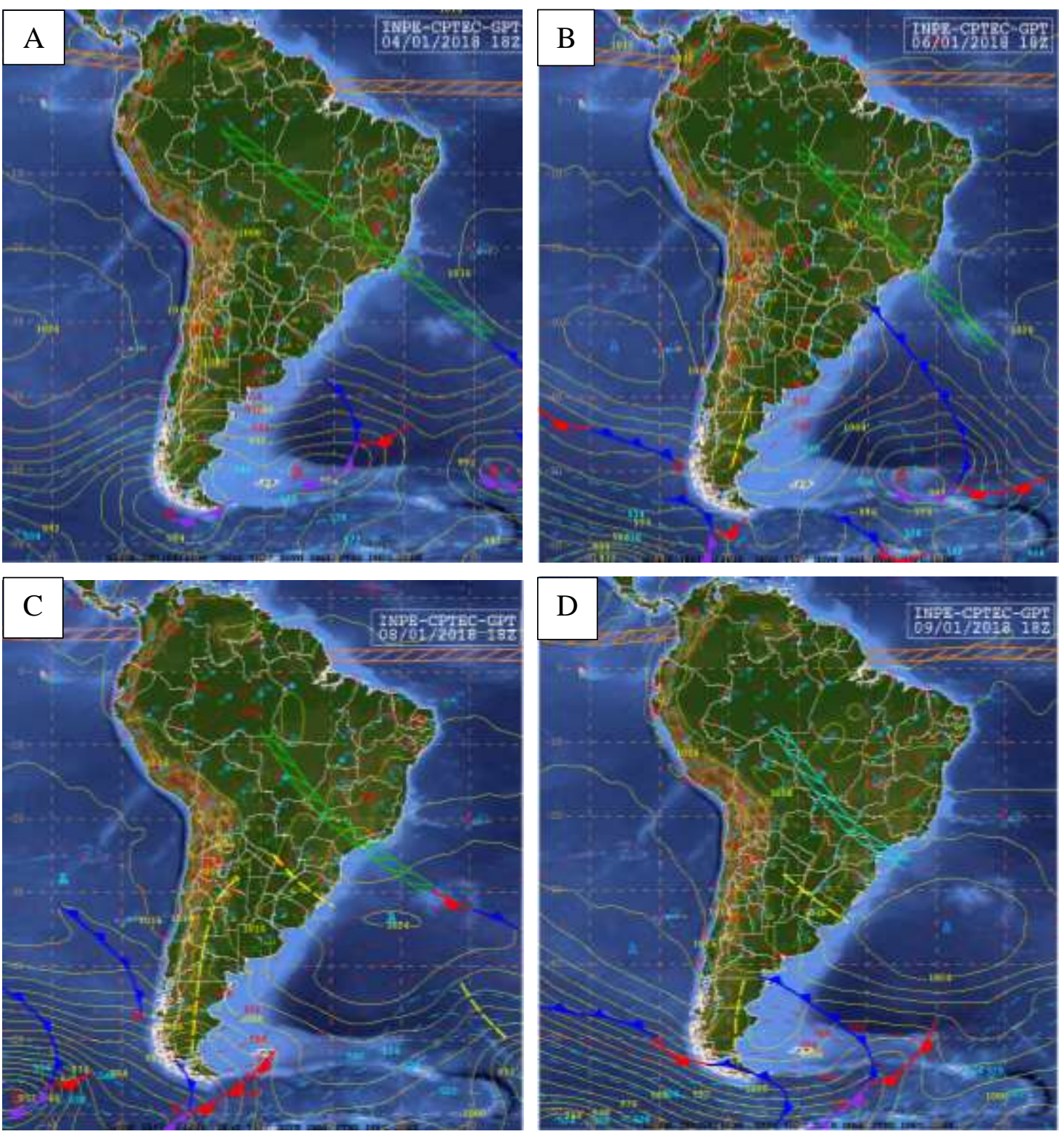

Source: CPTEC (2018).

Figure 4 shows the vertically integrated water vapor flux for the 4th, 6th, 7th, and 9th of January 2018. The transport of water vapor from the Amazon region to Southeastern Brazil is evident on the 6th. In the following days, a rise in the Pacific Ocean reversed the direction of the flux. The passages of the frontal system influence the system in all studied cases, as corroborated by the images of the synoptic charts. In case 1, for example, as the frontal system advances over the Continent and later dissipates, a high-pressure system over the Atlantic Ocean approaches the Continent, modifying the humidity flux pattern during the study case. 
Figure 4: Vertically integrated water vapor flux ( $\mathrm{km} / \mathrm{ms})$ for case 1. A) B) C) D).
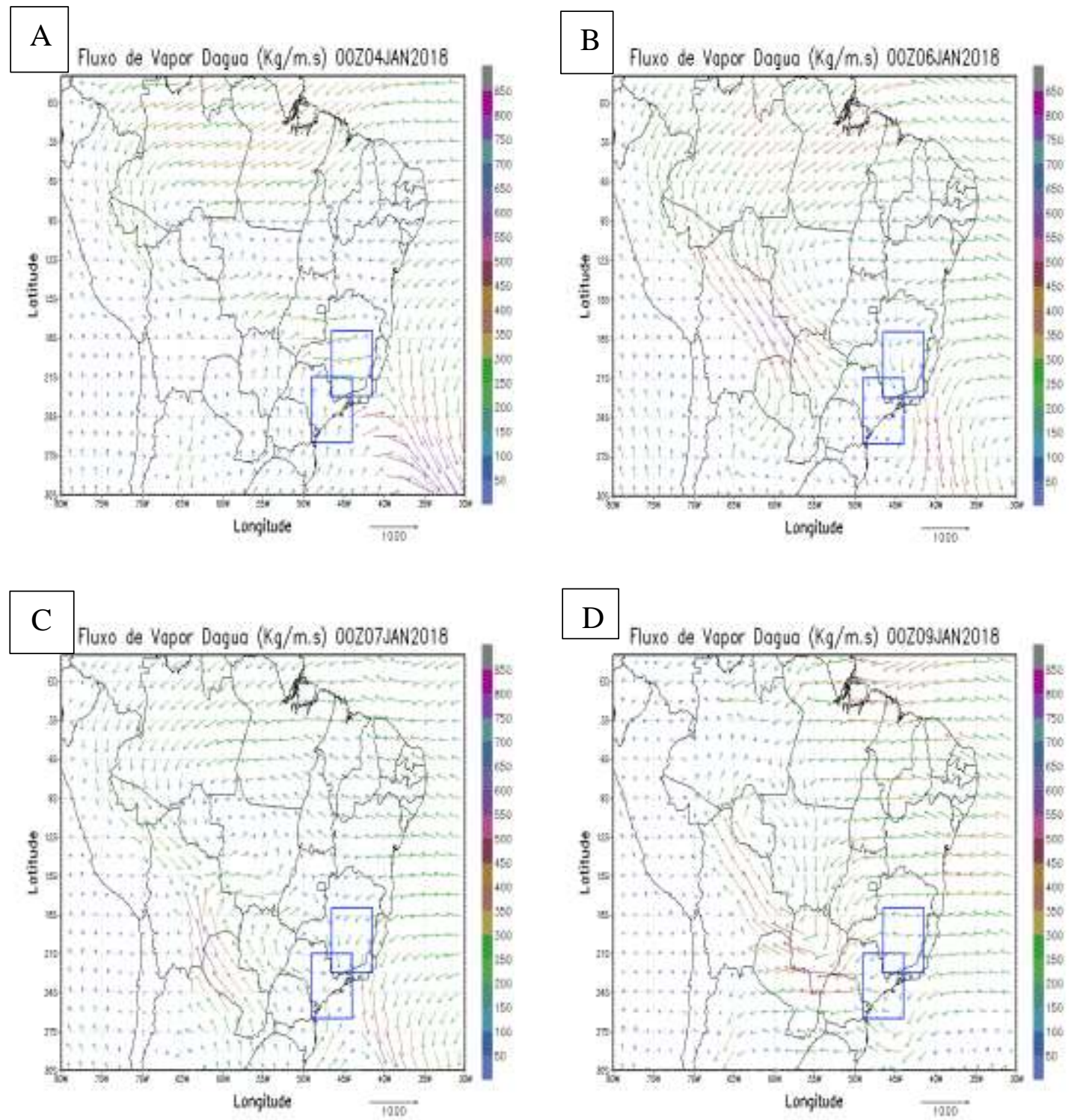

Source: Authors (2018).

The images of divergence on water vapor flow demonstrate the precipitation in the area with cloudiness associated with SACZ. As well as in the most eastern areas of the Andes, due to the transport of moisture.

The divergence field (Figure 5) on day 7 displays the formation of a convergence line directed from Northwest to Southeast, which occurred after the inversion of the flux verified on the previous day. It is important to emphasize that the areas in blue represent convergence of water vapor flux that is less than $-0.5 \times 10-3 \mathrm{~mm} / \mathrm{s}$. On the 9 th, the system is already in dissipation. 
Figure 5: Divergence of water vapor flux $\left(10^{-3} \mathrm{~mm} / \mathrm{s}\right)$ for case 1 . A) B) C) D).

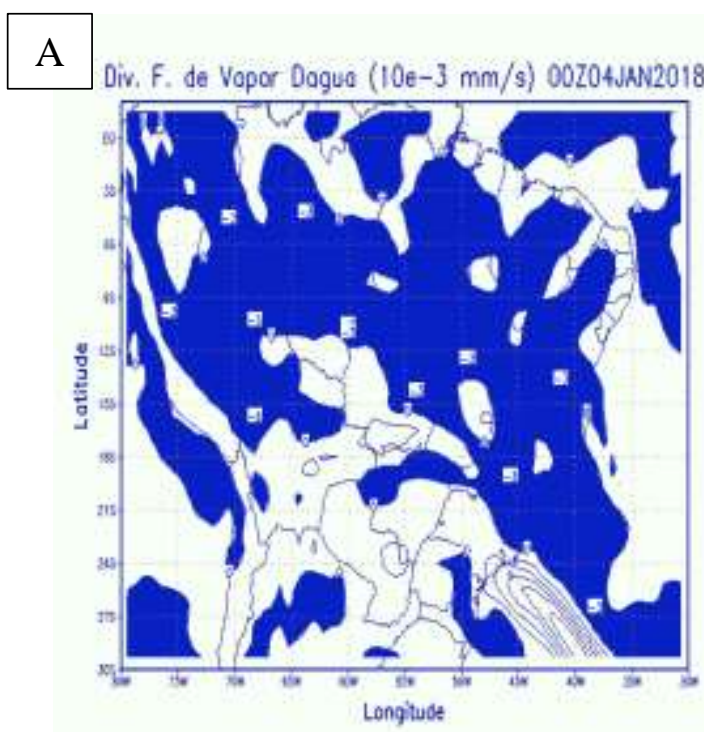

B Div. F, de Vopar Dogua (10e-3 mm/s) OOZO6 Uan2018
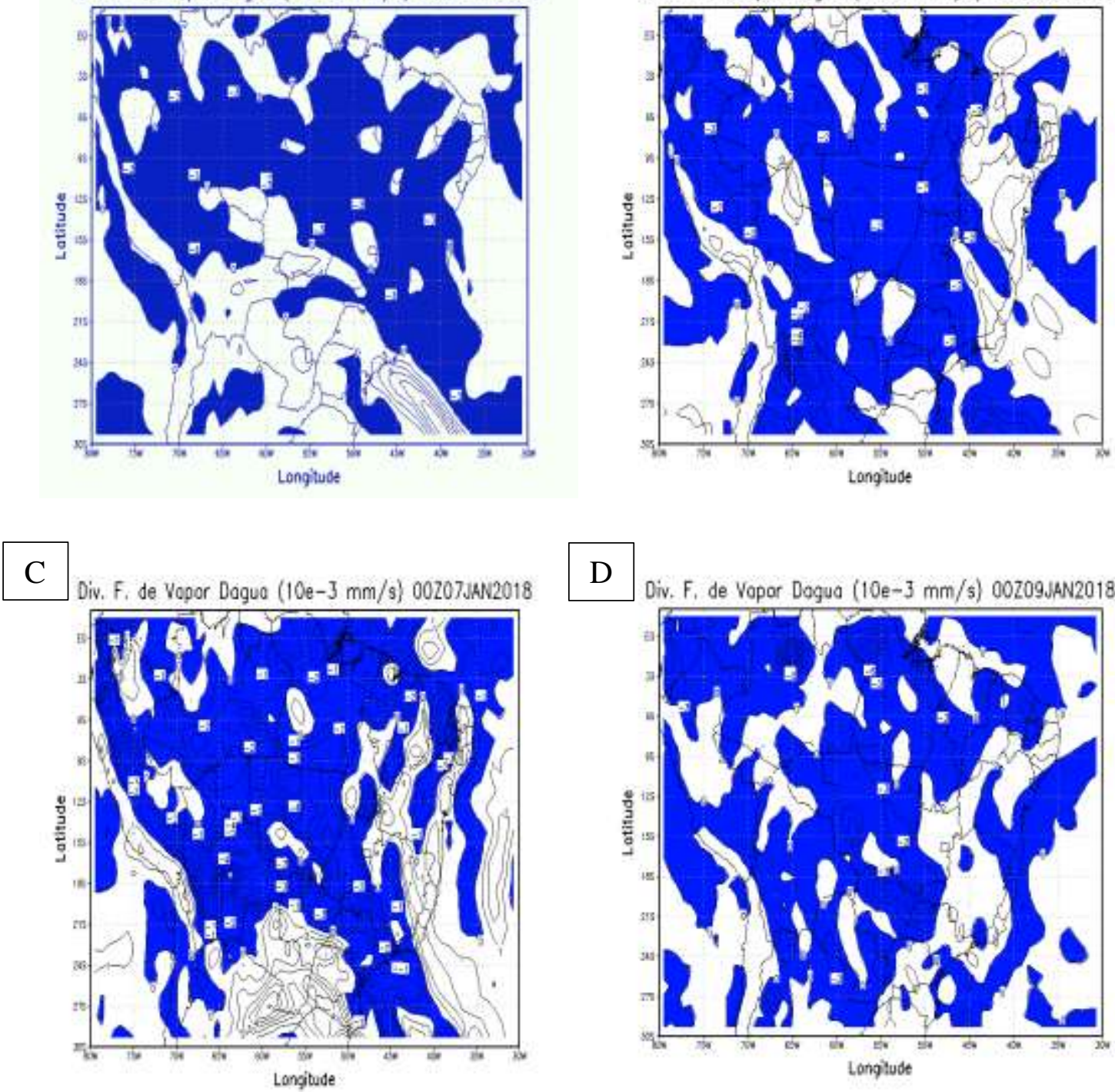

$\mathrm{D}$
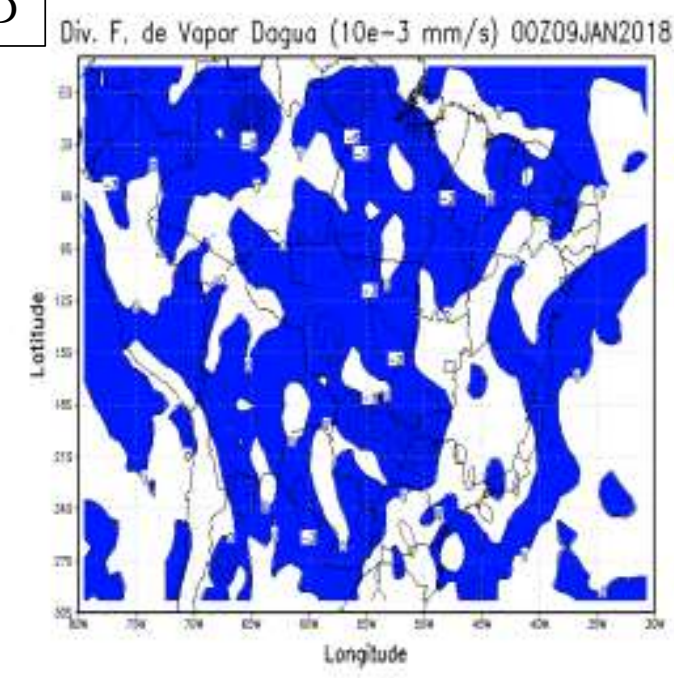

Source: Authors (2018).

Table 1 shows the water vapor balance for the Belo Horizonte and São Paulo sub-areas, displaying the flux entering and leaving each face, as well as the sum of the four faces. Values are expressed in $\mathrm{mm} /$ day and represent the daily average amount of rain in the area if all water vapor condenses and precipitates. Negative values indicate water vapor influx, and positive values indicate water vapor outputs. The negative resultant indicates that there was more water vapor entering than leaving, establishing an import and, consequently, water vapor sink. Positive values reflect the opposite, implying that the area was a source of water vapor.

In this sense, the average over the period indicates that the BH and SP subareas, -1.8 and $-3.6 \mathrm{~mm} / \mathrm{day}$, respectively, were water vapor importers and, consequently, sinks. In this case, precipitation was greater than the average evapotranspiration in the area. 
Table 1: Values in mm/day for case 1 , from $01 / 04 / 2018$ to $04 / 09 / 2018$.

\begin{tabular}{ccccccccccc}
\hline & \multicolumn{2}{c}{ FS } & \multicolumn{2}{c}{ FL } & \multicolumn{2}{c}{ FN } & \multicolumn{2}{c}{ FO } & \multicolumn{2}{c}{ Resultant } \\
Day & BH & SP & BH & SP & BH & SP & BH & SP & BH & SP \\
\hline 4 & $-2,9$ & $-20,0$ & 22,3 & 39,2 & 5,0 & $-1,3$ & $-41,0$ & $-1,5$ & $-16,6$ & 16,4 \\
5 & 7,1 & 2,1 & $-0,9$ & $-11,4$ & $-16,2$ & $-8,3$ & $-0,7$ & 19,0 & $-10,6$ & 1,5 \\
6 & 36,9 & 9,6 & $-10,6$ & 7,7 & $-9,0$ & $-24,0$ & $-13,2$ & $-1,2$ & 4,1 & $-7,9$ \\
7 & 30,7 & $-20,4$ & $-17,5$ & 7,3 & $-8,3$ & $-22,3$ & $-2,8$ & 16,5 & 2,1 & $-18,9$ \\
8 & 13,8 & $-31,2$ & $-20,2$ & $-8,6$ & $-1,6$ & $-12,6$ & 6,8 & 37,7 & $-1,1$ & $-14,7$ \\
9 & 10,3 & $-10,6$ & $-26,8$ & $-16,1$ & 0,4 & $-10,0$ & 27,3 & 39,1 & 11,2 & 2,4 \\
\hline Average & 16,0 & $-11,8$ & $-8,9$ & 3,0 & $-4,9$ & $-13,1$ & $-3,9$ & 18,3 & $-1,8$ & $-3,6$ \\
\hline
\end{tabular}

Source: Authors (2018).

What was presented in Table 1 is now summarized in Figure 6, which expresses the water vapor balance in each of the faces, as well as the resulting value.

There is a negative flux on the north and south faces of the São Paulo sub-area, while all faces of the Belo Horizonte sub-area have a negative flux, except for the south face. Negative values indicate water vapor entering the area. Although the flux on the east and west faces of São Paulo and Belo Horizonte is leaving the area, the resulting values indicate that more water vapor entered the rectangle than it left, i.e., $-1.8 \mathrm{~mm} /$ day for $\mathrm{BH}$, and $-3.6 \mathrm{~mm} /$ day for $\mathrm{SP}$. This result indicates that the average precipitation in the two subareas exceeded precipitation, with greater intensity in SP.

Figure 6: Average of water vapor flux balance (mm/day) for case 1. A) Belo Horizonte B) São Paulo.
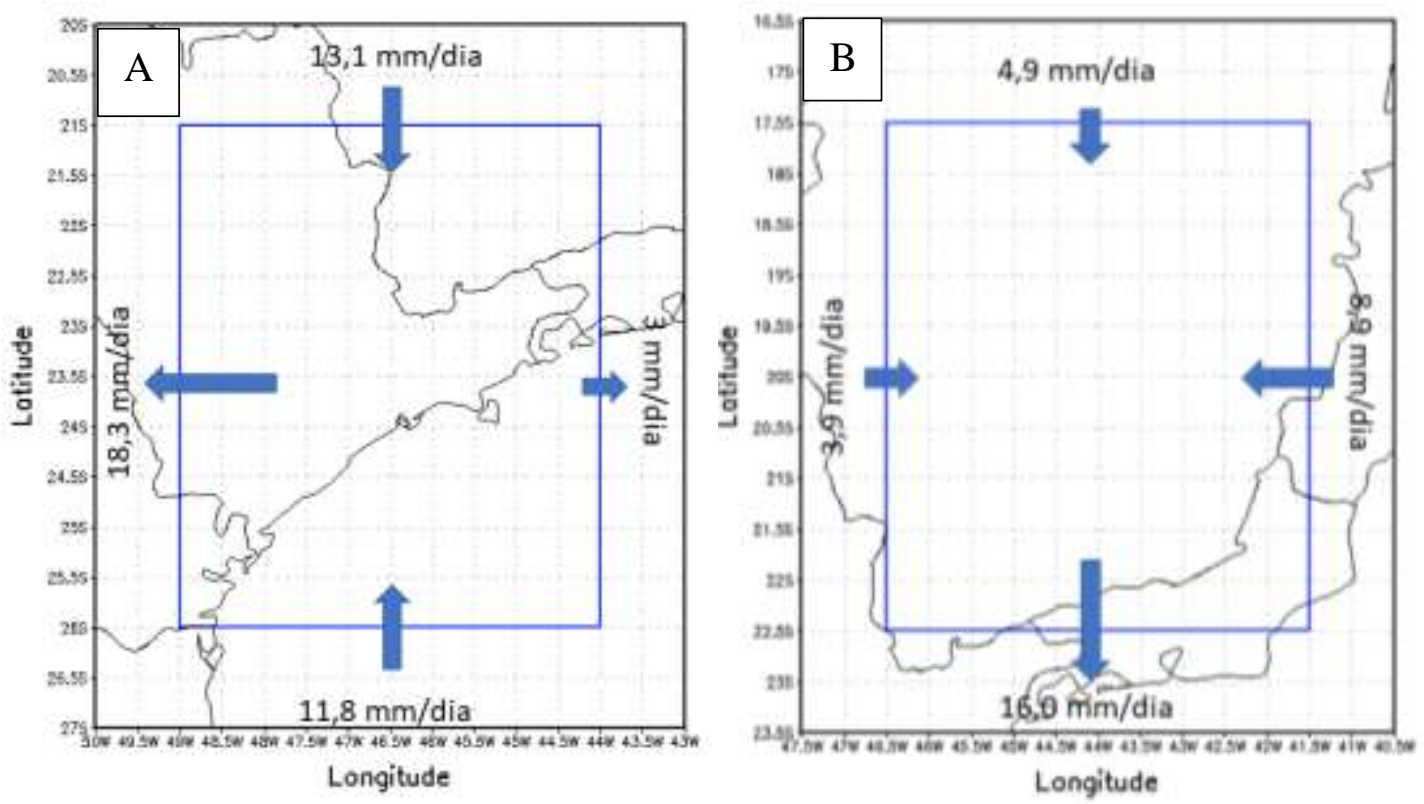

Source: Authors (2018).

\subsection{Case 2}

In case 2, we present an event with an extended duration of 10 days, from January 30th to February 8th. Satellite images (Figure 7) and surface charts (Figure 8) demonstrate that this case was more northerly than case 1. Most of it occurred over the northern region of Minas Gerais, but also reaching the south of Bahia on certain days. As in case 1, case 2 was also influenced by the passage of frontal systems. 
Figure 7: Satellite image in the enhanced infrared channel for the case 2 period at 18 UTC. A) B) C) D).

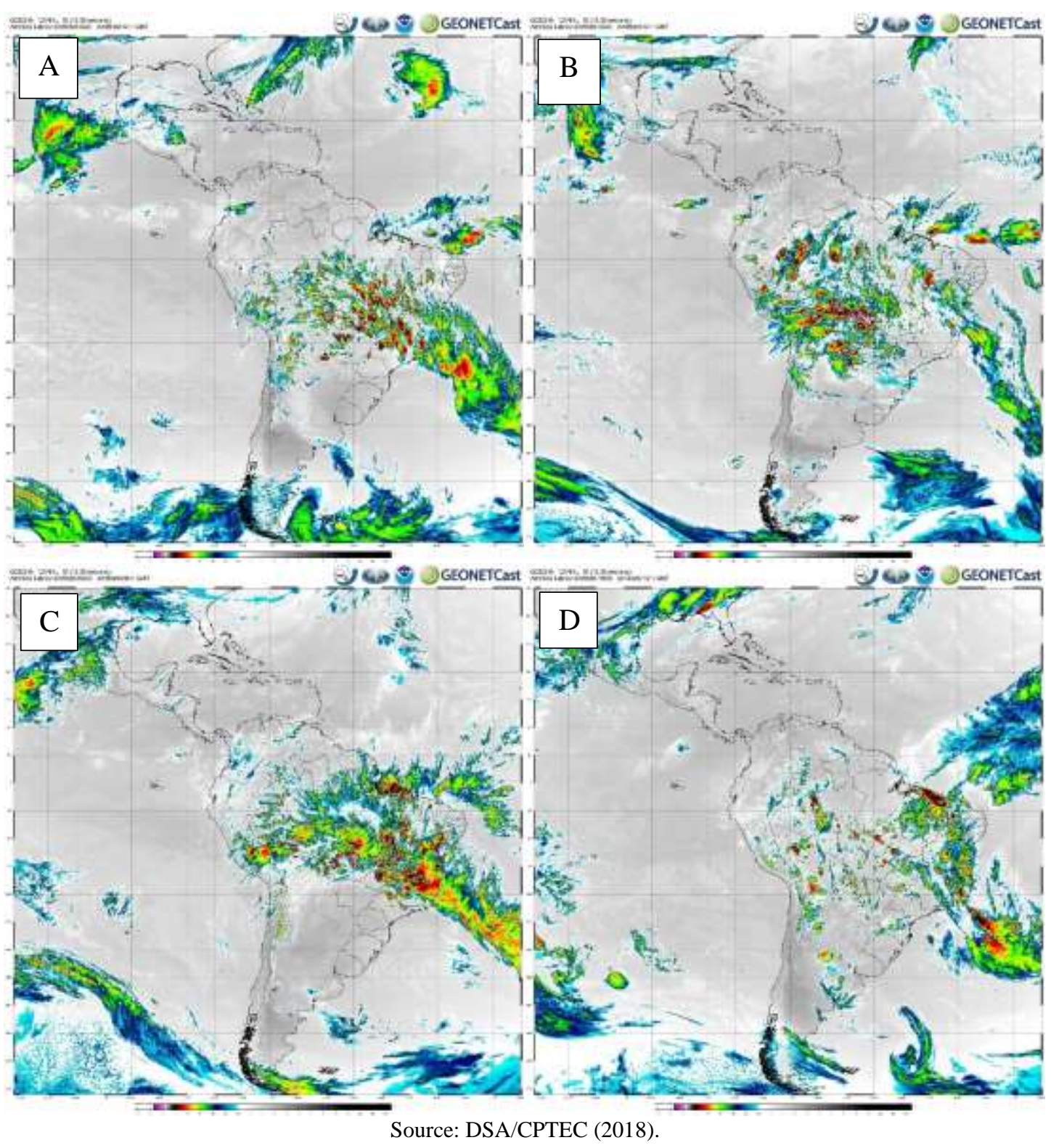


Figure 8: Surface synoptic charts for the case 2 period at 18 UTC. A) B) C) D).
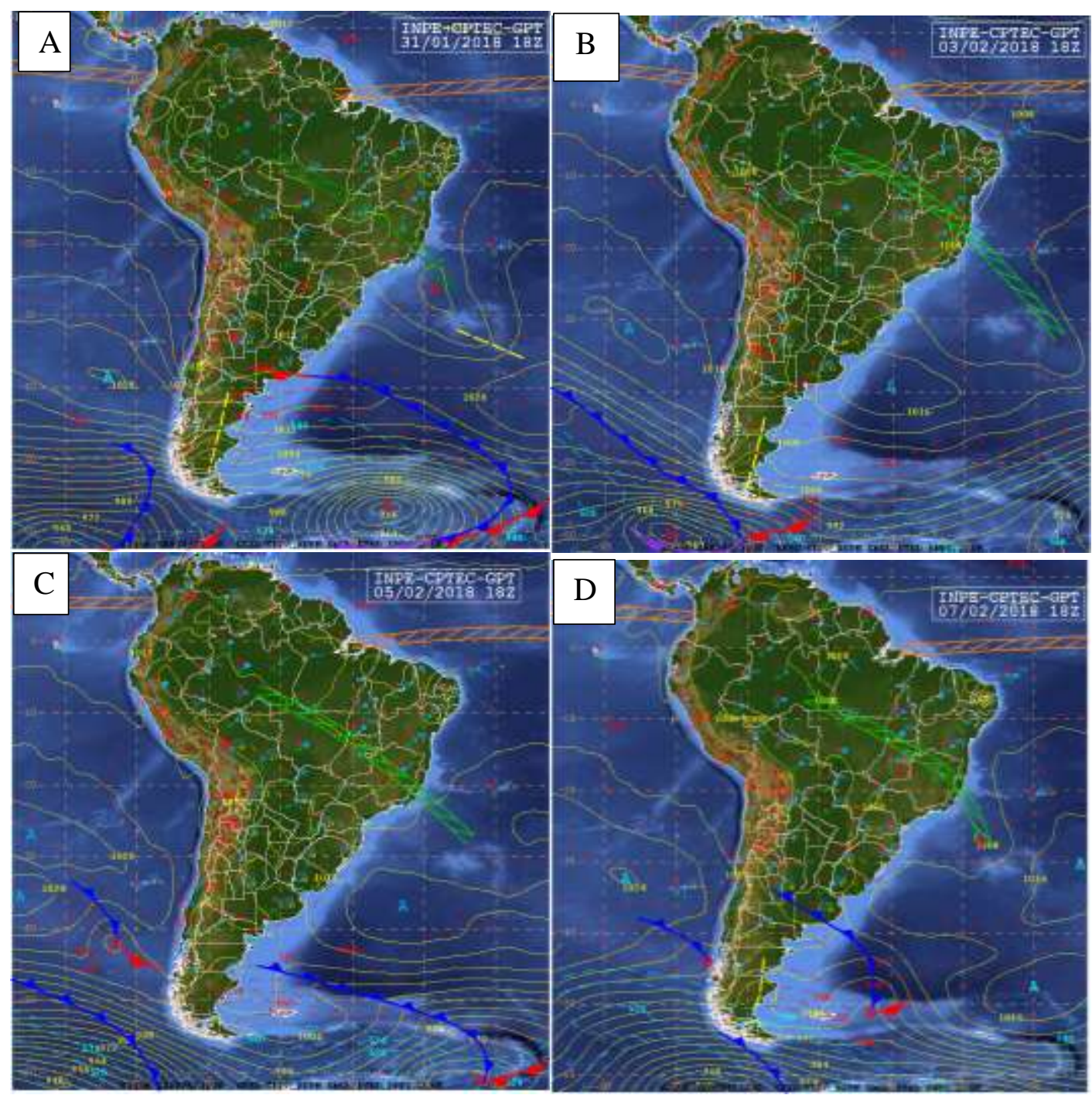

Source: CPTEC (2018).

Figure 9 shows the vertically integrated water vapor flux for January 30th, February 3rd, 6th, and 9th. Unlike the previous case, the water vapor flux in case 2 was not so intense at the beginning. However, on February 6th, the flow was very intense in the north-south direction over the BH sub-area. It was the influence of a cyclonic vortex over Northeastern Brazil and the low pressure over the state of Rondônia, also in association to the high pressure due to a cold front. According to the image on the 9th, the flux returned further west as the rise of the Pacific Ocean approached the continent again. Similar to case 1, case 2 also modified the flux of water vapor over the studied areas according to the passage of frontal systems. At the beginning of the SACZ, the rise over the Atlantic Ocean was far from the Continent. As the days passed, the frontal system entered the study areas and changed in the water vapor flux pattern, intensifying the flux predominantly on the north face. 
Research, Society and Development, v. 10, n. 13, e455101321187, 2021

(CC BY 4.0) | ISSN 2525-3409 | DOI: http://dx.doi.org/10.33448/rsd-v10i13.21187

Figure 9: Vertically integrated water vapor flux (kg/m.s) for case 2. A) B) C) D).

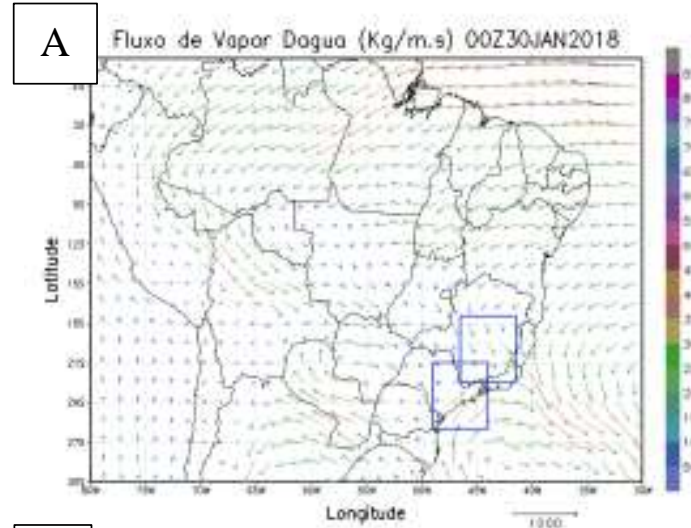

$\mathrm{C}$ Fluxo de Vapor Doguo $(\mathrm{Kg} / \mathrm{m}, \mathrm{s})$ 00Z06FEB 2018

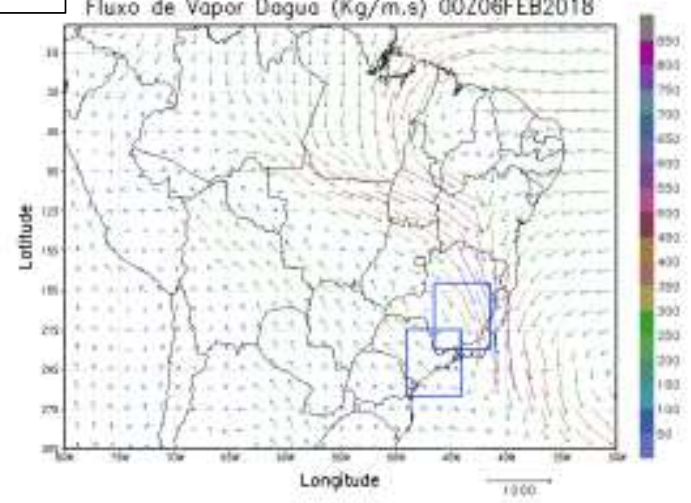

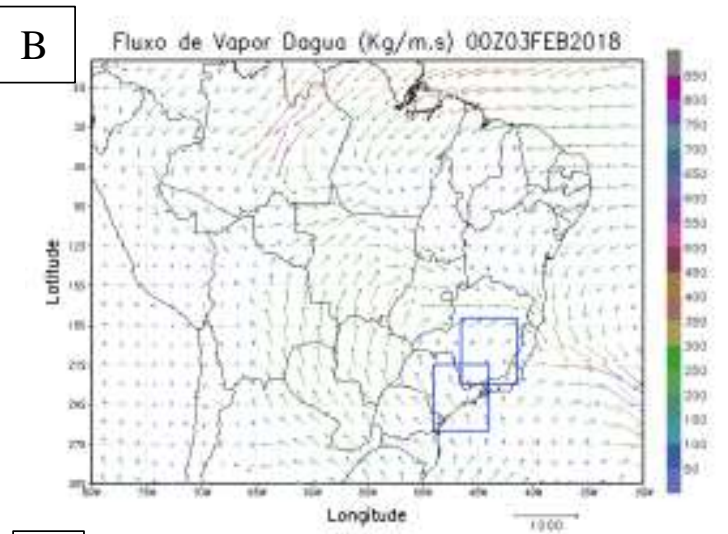

$\mathrm{D}$

D Fluxo de Vapor Dogua $(\mathrm{Kg} / \mathrm{m}, \mathrm{s})$ 00ZO9FEB2018

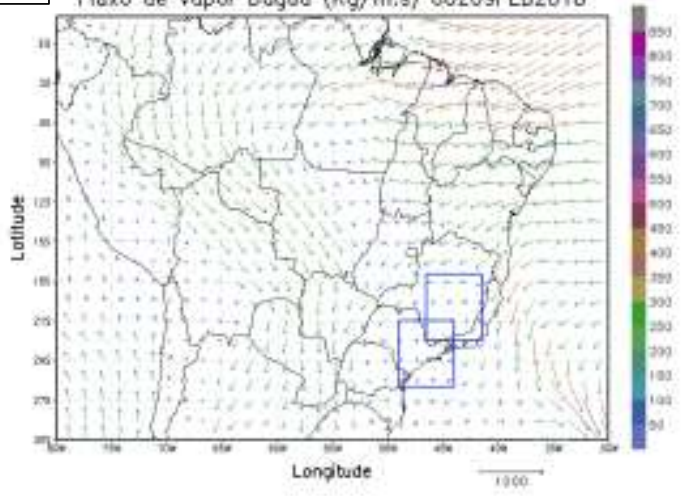

Source: Authors (2018).

The divergence images in the water vapor flux (Figure 10) show organized precipitation in the northwest-southeast direction for the highlighted days. We draw attention to the intensified value over the BH sub-area on the 6th and the divergence over the SP sub-area, which is in agreement with both the satellite images and the field of water vapor flux. 
Figure 10: Divergence of water vapor flux $\left(10^{-3} \mathrm{~mm} / \mathrm{s}\right)$ for case 2. A) B) C) D).

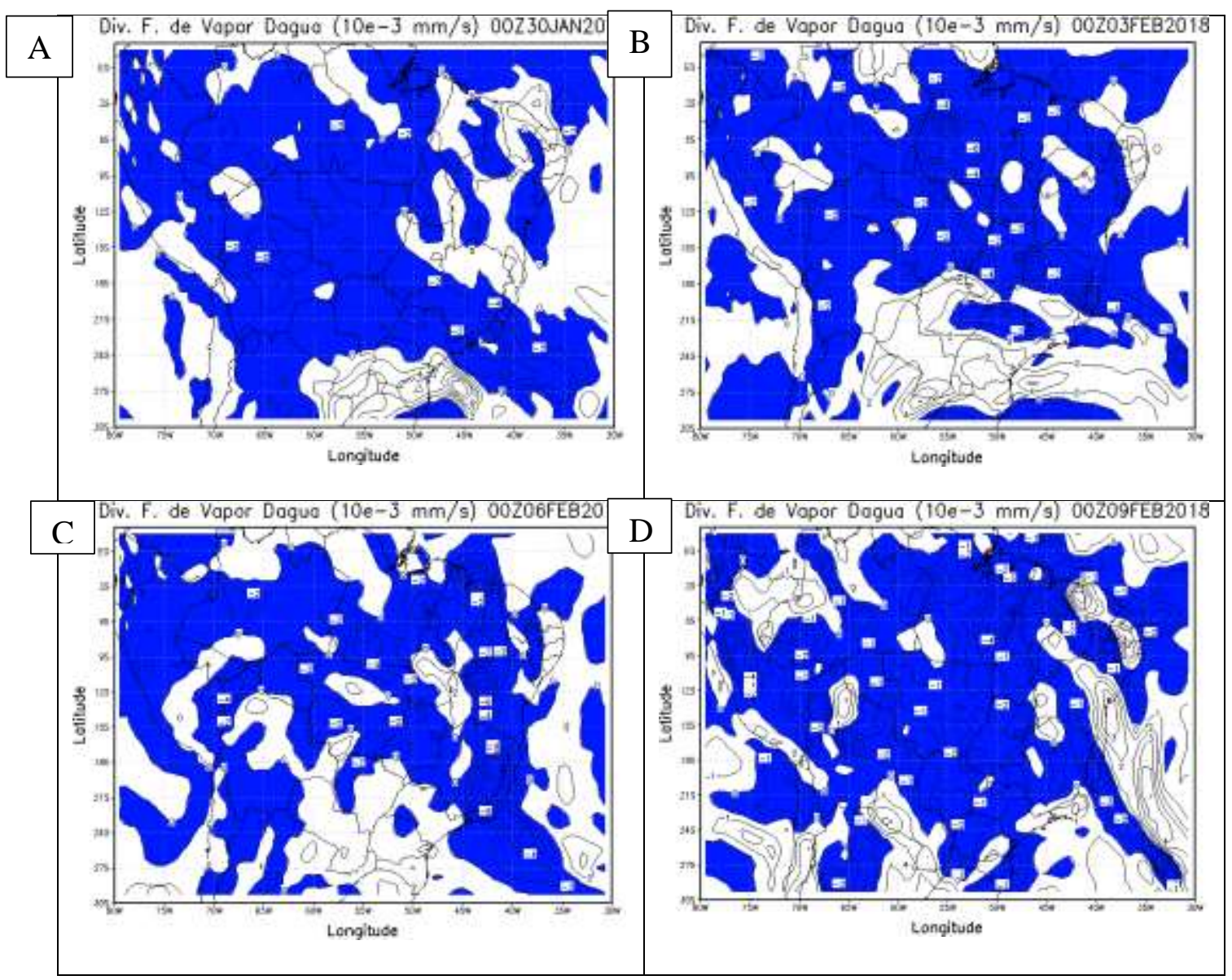

Source: Authors (2018).

Table 2 shows the values for the water vapor balance in subareas Belo Horizonte and São Paulo, respectively. In this case, the resulting flux in sub-area SP presents positive values. As for the BH sub-area, the resulting value is rather negative, which is also in agreement with Figures 06 and 07. As this case was located predominantly over the BH sub-area, the values expressed in $\mathrm{mm}$ /day indicate that only the east face exported water vapor in the BH sub-area. SP, on the other hand, only the south face imported water vapor. Therefore, the average for the period indicates that the BH sub-area, with $-12.9 \mathrm{~mm} / \mathrm{day}$, is an importer of water vapor and thus a sink. The SP subarea, with $2.0 \mathrm{~mm} / \mathrm{day}$, is then a source. 
Table 2: Values in mm/day for the Belo Horizonte (BZ) and São Paulo (SP) sub-areas, from 01/30/2018 to 02/08/2018.

\begin{tabular}{ccccccccccc}
\hline & \multicolumn{2}{c}{ FS } & \multicolumn{2}{c}{ FL } & \multicolumn{2}{c}{ FN } & \multicolumn{2}{c}{ FO } & \multicolumn{2}{c}{ Resultant } \\
Day & BH & SP & BH & SP & BH & SP & BH & SP & BH & SP \\
\hline 30 & $-2,5$ & $-33,9$ & 20,5 & 38,5 & $-21,5$ & $-5,2$ & $-13,0$ & $-7,4$ & $-16,4$ & $-7,9$ \\
31 & $-32,7$ & $-35,6$ & 43,8 & 26,3 & $-5,9$ & 21,2 & $-31,8$ & 8,1 & $-26,5$ & 20,0 \\
1 & $-20,1$ & $-42,2$ & 25,4 & $-3,8$ & 2,0 & 20,6 & 2,0 & 24,8 & 9,3 & $-0,6$ \\
2 & $-10,5$ & $-23,2$ & 22,4 & 0,3 & $-22,9$ & 4,9 & $-0,2$ & 13,7 & $-11,2$ & $-4,4$ \\
3 & $-15,6$ & $-19,3$ & 16,0 & 0,5 & 2,0 & 11,7 & $-8,4$ & 11,5 & $-6,0$ & 4,4 \\
4 & $-9,8$ & $-30,9$ & $-1,3$ & $-7,8$ & $-18,7$ & 5,0 & 23,5 & 34,6 & $-6,3$ & 0,8 \\
5 & $-2,1$ & $-13,1$ & $-21,3$ & $-23,5$ & $-38,1$ & 6,4 & 33,3 & 30,4 & $-28,1$ & 0,1 \\
6 & 14,1 & $-7,2$ & 10,3 & $-10,1$ & $-70,0$ & 0,0 & 6,0 & 20,6 & $-39,6$ & 3,3 \\
7 & 7,0 & $-11,1$ & 33,6 & 11,2 & $-22,4$ & 0,8 & $-21,0$ & 2,1 & $-2,7$ & 2,9 \\
8 & $-10,6$ & $-14,9$ & 20,4 & 10,9 & 2,1 & 9,2 & $-13,2$ & $-3,6$ & $-1,4$ & 1,5 \\
\hline Average & $-8,3$ & $-23,2$ & 17,0 & 4,2 & $-19,3$ & 7,5 & $-2,3$ & 13,5 & $-12,9$ & 2,0 \\
\hline
\end{tabular}

Source: Authors (2018).

What was discussed in Table 2 is now expressed in Figure 11, the water vapor balance on each face and the resultant value.

In this case, there is a negative flux on the north, south, and west faces of the BH sub-area. In the SP sub-area, there is negative flux only on the south face. These balance sheet amounts follow what has been presented. The resultant, negative at $\mathrm{BH}$ and positive at $\mathrm{SP}$, indicate that the average precipitation in $\mathrm{BH}$ exceeded evaporation. In SP, evaporation was greater than precipitation.

Figure 11: Average of water vapor flux balance (mm/day) for case 2. A) Belo Horizonte B) São Paulo.
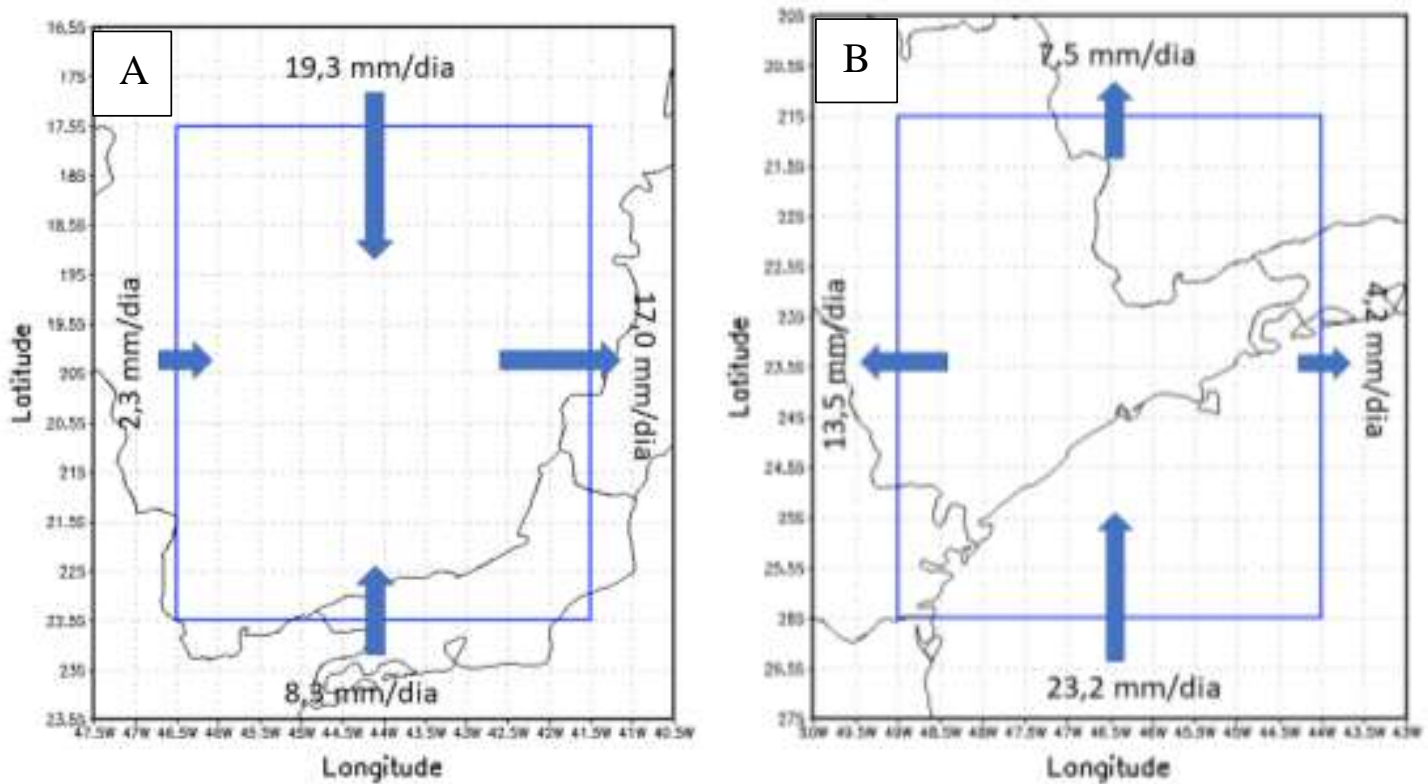

Source: Authors (2018). 


\section{Conclusion}

The amount of water vapor is increased after passing through the Amazon region. Thereafter, it is forced to flow to the South and Southeast of South America because of a physical barrier. This move corroborates the importance of the Bolivia hights for the maintenance of the South Atlantic Convergence Zone, as manifested in the images in this paper.

We observed a characteristic profile of atmospheric water vapor sinks in both subareas under analysis in this study. It means that the humidity transported to the area was precipitated, except for the São Paulo sub-area in case 2. There was a water vapor export, suggesting that the São Paulo sub-area served as a source of atmospheric water vapor. This difference observed only in the second sub-area of case 2 may be associated with the basic atmospheric flow, which was more perpendicular to the area than in case 1. The high pressure found over the Atlantic Ocean is another factor that may have influenced this event. Nevertheless, it is closer to the South American continent in case 2 than in case 1.

It is imperative to monitor occurrences of SACZ because they are crucial for the quality of rainy seasons over the Brazilian South and Southeast. In addition, it can afflict residents for the high population density. Together with the disorderly growth of cities, this factor can be fatal for people who live on the streets, hillsides, and other risky places. It is also detrimental to citizens' mobility, agriculture, and the local economy.

\section{Acknowledgments}

To the Federal University of Campina Grande, in particular the Department of Atmospheric Sciences (DCA/UACA) for the opportunity and financial support to carry out this research.

\section{References}

Ceped/Ufsc. Centro de Estudos e Pesquisas em Engenharia e Defesa Civil (2013). Atlas Brasileiro de Desastres Naturais.

Dee, D. P., Uppala, S. M., Simmons, A. J., Berrisford, P., Poli, P., Kobayashi, S., \& Vitart, F. (2011). The ERA-Interim reanalysis: Configuration and performance of the data assimilation system. Quarterly Journal of the royal meteorological society, 137(656), 553-597.

Dee, D. P., Uppala, S. M., Simmons, A. J., Berrisford, P., Poli, P., Kobayashi, S., \& Vitart, F. (2011). The ERA-Interim reanalysis: Configuration and performance of the data assimilation system. Quarterly Journal of the royal meteorological society, 137(656), 553-597.

Kodama, Y. M. (1992). Large-scale common features of subtropical precipitation zones (the Baiu frontal zone, the SPCZ, and the SACZ), Part I: Characteristics of subtropical frontal zones. Journal of the Meteorological Society of Japan, 70, 813-835.

Licco, E. A. \& Seo, E. S. M. (2013). Perigos e riscos naturais: estudo de caso do Jardim Pantanal. InterfacEHS-Revista de Saúde, Meio Ambiente e Sustentabilidade, $8(1)$.

Licco, E. A., \& Mac Dowell, S. F. (2015). Alagamentos, Enchentes Enxurradas e Inundações: Digressões sobre seus impactos sócio econômicos e governança. Revista de Iniciação Científica, Tecnológica e Artística, 5(3), 159-174.

Peixoto, J. P. (1973). Atmospheric vapor flux computations for hydrological purposes. WMO contribution to the International Hydrological Decade (IHD).

Peixoto, J. P., Oort, A.H. (1992). Physics of climate. American Institute of Physics, 520f.

Quadro, M. F. L. D., Dias, M. A. F. D. S., Herdies, D. L., \& Gonçalves, L. G. G. D. (2012). Análise climatológica da precipitação e do transporte de umidade na região da ZCAS através da nova geração de reanálises. Revista Brasileira de Meteorologia, 27(2), 152-162.

Rao, V. B., \& Marques, V. S. (1984). Water vapor characteristics over Northeast Brazil during two contrasting years. Journal of climate and applied meteorology, $23(3), 440-444$

Simmons, A. J. \& Burridge, D. M. (1981). An energy and angular-momentum conserving vertical finite-difference scheme and hybrid vertical coordinates. Monthly Weather Review, 109(4), 758-766.

Stüker, E. Schuster, C. H. Schuster, J. J. Santos, D. C., Medeiros, L. E., Costa, F. D. \& Puhales, F. S. (2016). Comparação entre os dados de vento das reanálises meteorológicas ERA-Interim e CFSR com os dados das estações automáticas do INMET no Rio Grande do Sul. Ciência e Natura, $38,284-290$. 